\title{
PROJECT BASED LEARNING TERINTEGRASI STEM UNTUK MENINGKATKAN KETERAMPILAN KERJA ILMIAH SISWA
}

\author{
Aris Sugiharto \\ SMA Negeri 1 Rawalo \\ Email: arissugiharto212@gmail.com
}

(Diterima: 12 Oktober 2020; Disetujui: 12 Desember 2020; Publikasi: 31 Desember 2020)

\begin{abstract}
ABSTRAK
Penelitian ini bertujuan untuk meningkatkan keterampilan kerja ilmiah siswa dengan menggunakan model Project Based Learning terintegrasi STEM dengan media akuaponik pada materi pertumbuhan dan perkembangan makhluk hidup. Metode yang digunakan adalah penelitian tindakan kelas. Penelitian dilaksanakan dalam dua siklus di kelas XII MIPA-3 SMA Negeri 1 Rawalo pada materi pertumbuhan dan perkembangan makhluk hidup dengan media akuaponik. Aspek keterampilan kerja ilmiah siswa yang diamati adalah keterampilan mengajukan pertanyaan, merencanakan percobaan, melakukan pengamatan, menggunakan alat/bahan, menganalisis hasil percobaan, membuat kesimpulan, menyusun laporan percobaan, dan keterampilan presentasi. Pada siklus I terjadi kenaikan keterampilan ilmiah kerja siswa sebesar $13,79 \%$, sedangkan pada siklus II terjadi kenaikan sebesar $41,38 \%$. Selain keterampilan kerja ilmiah, pengetahuan konsep siswa juga meningkat sebesar9,62\%. Simpulan dari penelitian ini bahwa penerapan model Project Based Learning terintegrasi STEM dengan media akuaponik dapat meningkatkan keterampilan ilmiah siswa. Model Project Based Learning terintegrasi STEM dengan media akuaponik dapat dijadikan alternatif model pembelajaran untuk meningkatkan keterampilan ilmiah siswa pada materi pertumbuhan dan perkembangan makhluk hidup.
\end{abstract}

Kata kunci: Keterampilan Kerja Ilmiah, Project Based Learning, STEM

\section{ABSTRACT}

This research aims to improve students' scientific skills by using Project Based Learning models integrated STEM with akuaponic media on the growth and development materials of living things. The method used is class action research. The research was conducted in two cycles in grade XII MIPA-3 SMA Negeri 1 Rawalo on the growth and development materials of living things with aquaponic media. Aspects of students' scientific skills are the skills of asking questions, planning experiments, making observations, using tools/materials, analyzing experiment results, making conclusions, compiling experimental reports, and presentation skills. In cycle I there was a $13.79 \%$ increase in students' scientific skills, while in cycle II there was a $41.38 \%$ increase. In addition to scientific skills, student concept knowledge also increased by $9.62 \%$. The conclusion of this study is that the application of the PjBL model Integrated STEM with aquaponic media can improve students' scientific skills. PJBL model integrated STEM of aquaponic media can be used as an alternative 
learning model to improve students' scientific skills on the growth and development materials of living things.

Keywords: Scientific Skills, Project Based Learning, STEM

\section{PENDAHULUAN}

Pengembangan pembelajaran biologi SMA tidak terlepas dari tren masa depan dalam lingkup biologi, terutama kebutuhan kehidupan dari penerapan biologi dalam kehidupan sehari-hari. Untuk menjawab kebutuhan jaman, pembelajaran biologi dikembangkan dengan kompetensi yang menuntut kecakapan biologi yang berupa keterampilan kerja ilmiah. Pembelajaran biologi di SMA Negeri 1 Rawalo selama ini belum dibekali keterampilan ilmiah dengan baik sehingga penguasaan konsep biologi masih rendah. Siswa yang menguasai konsep materi pertumbuhan dan perkembangan makhluk hidup pada soal UNBK 2018 sebesar 70\%, sedangkan siswa yang belum mengusai konsep sebesar 30\%. Untuk meningkatkan penguasaan konsep siswa pada materi pertumbuhan dan perkembangan makhluk hidup, perlu diadakan sebuah tindakan perbaikan pembelajaran. Saputra (2012) melaporkan bahwa agar pengetahuan konsep siswa meningkat dengan optimal, perlu ditingkatkan keterampilan kerja ilmiah siswa.

Penerapan model Project Based Learning (PjBL) dalam pembelajaran sains dapat meningkatkan keterampilan kerja ilmiah siswa (Ozer \& Ozkan, 2012). Pembelajaran PjBL merupakan model pembelajaran yang berpusat pada siswa dan memberikan pengalaman belajar yang bermakna bagi siswa (Afriana, 2015). Pengalaman belajar siswa dibangun berdasarkan produk yang dihasilkan dalam proses pembelajaran, sehingga siswa memiliki kompetensi pada tiga dimensi yaitu sikap, pengetahuan, dan keterampilan. Pembelajaran saat ini juga perlu mengikuti perkembangan era globalisasi, salah satunya dengan mengintegrasikan Science, Technology, Engineering, dan Mathematics (STEM). Keterkaitan antara sains dan teknologi maupun ilmu lain tidak dapat dipisahkan dalam pembelajaran sains. STEM merupakan disiplin ilmu pengetahuan yang berkaitan erat satu sama lain. Sains memerlukan matematika sebagai alat dalam mengolah data, sedangkan teknologi dan teknik merupakan aplikasi dari sains. Pendekatan STEM dalam pembelajaran diharapkan dapat menghasilkan pembelajaran yang bermakna bagi siswa melalui integrasi pengetahuan, konsep, dan keterampilan secara sistematis. Capraro et al. (2013) mengungkapkan bahwa PjBL terintegrasi STEM dapat memberikan tantangan dan memotivasi siswa karena melatih bersikap dan berpikir kritis, analisis, dan meningkatkan keterampilan siswa. 
Penerapan model PjBL terintegrasi STEM umumnya lebih menekankan pada proses desain, namun pada penelitian ini dilaksanakan sampai dengan pembuatan proyek yaitu mendesain dan membuat media akuaponik dalam pembelajaran pertumbuhan dan perkembangan makhluk hidup. Melalui model PjBL terintegrasi STEM dengan akuaponik diharapkan terjadi peningkatan keterampilan kerja ilmiah siswa sehingga penguasaan konsep materi pertumbuhan dan perkembangan makhluk hidup juga meningkat.

\section{KAJIAN PUSTAKA}

\section{Project Based Learning (PjBL)}

Goodman dan Stivers (2010) mendefinisikan bahwa PjBL merupakan model pembelajaran yang dibangun di atas kegiatan pembelajaran dan tugas nyata yang memberikan tantangan bagi siswa yang terkait dengan kehidupan sehari-hari untuk dipecahkan secara berkelompok. PjBL berpusat pada siswa dan memberikan pengalaman belajar yang bermakna. Pengalaman belajar maupun konsep dibangun berdasarkan produk yang dihasilkan dalam proses pembelajaran berbasis proyek (Afriana, 2015). Menurut Grant (2002), pada PjBL siswa melakukan suatu investigasi yang mendalam terhadap suatu topik. Siswa secara konstruktif melakukan pendalaman pembelajaran dengan pendekatan berbasis riset terhadap permasalahan dan pertanyaan yang berbobot, nyata, dan relevan. PjBL disebut sebagai kerja

proyek yang memuat tugas-tugas kompleks berdasarkan kepada pertanyaan dan permasalahan yang sangat menantang dan menuntun siswa untuk merancang, memecahkan masalah, membuat keputusan, melakukan kegiatan investigasi, serta memberikan kesempatan siswa untuk bekerja secara mandiri (Made, 2014).

\section{STEM (Science, Technology, Engineering, and Mathematics)}

STEM merupakan suatu pendekatan pembelajaran antara dua atau lebih dalam komponen STEM dengan disiplin ilmu lain (Becker dan Park, 2011). STEM dapat diintegrasikan dalam semua tingkat pembelajaran karena pelaksanaannya memiliki aspek seperti kecerdasan, kreativitas, dan kemampuan desain tidak tergantung pada usia (Sanders et al, 2011). Selain mengembangkan konten pengetahuan dibidang sains, teknologi, teknik dan matematika, STEM juga berupaya untuk menumbuhkan keterampilan seperti penyelidikan ilmiah dan kemampuan memecahkan masalah. Melatih keterampilan pemecahan masalah yang didukung dengan perilaku ilmiah (Asmuniv, 2015).

Karakter STEM lebih menekankan pada proses desain. Proses mendesain adalah pendekatan sistematis dalam mengembangkan solusi dari masalah dengan hasil akhir yang jelas (Capraro et al., 2013). Proses pembelajaran STEM dalam aplikasinya terdiri dari lima 
langkah, setiap langkah bertujuan untuk mencapai proses secara spesifik. Langkah dalam proses pembelajaran STEM yang efektif menurut Laboy-Rush (2010) terdiri dari refleksi (reflection), penelitian (research), penemuan (discovery), aplikasi (application), dan mengomunikasikan (communication).

\section{Keterampilan Kerja Ilmiah}

Keterampilan kerja ilmiah merupakan suatu proses yang dilakukan oleh siswa melalui suatu metode ilmiah untuk mendapatkan jawaban dari suatu permasalahan (Saputra et. al, 2012). Menurut Rustaman (2007), keterampilan kerja ilmiah dianggap sebagai perluasan metode ilmiah dan diartikan sebagai scientific inquiry yang diterapkan dalam belajar sains dan kehidupan. Scientific inquiry penting sekali dikembangkan karena memungkinkan siswa menggunakan berpikir tingkat tinggi dalam pemecahan masalah dan mengembangkan berpikir kritis yang tertanam dalam berbagai proses keilmuan. Bekerja ilmiah mengintegrasikan sains ke dalam kegiatan-kegiatan pembelajaran yang membekali siswa memperoleh pengalaman secara langsung.

Keterampilan kerja ilmiah mencakup kecerdasan intelektual dan kecerdasan emosional. Menurut Rustaman (2003), kecerdasan intelektual dalam keterampilan bekerja ilmiah meliputi: (1) mengajukan pertanyaan, (2) merencanakan percobaan/penyelidikan, (3) melakukan pengamatan, (4) menggunakan alat/bahan, (5) menganalisis hasil percobaan, (6) membuat kesimpulan, (7) menyusun laporan percobaan, dan (8) keterampilan presentasi. Aspek keterampilan bekerja ilmiah tersebut yang digunakan sebagai indikator keterampilan dalam penelitian ini.

\section{Pembelajaran PjBL Terintegrasi STEM}

Pembelajaran PjBL terintegrasi STEM adalah pembelajaran menggunakan model pembelajaran PjBL dengan pendekatan STEM. Adapun sinteks pembelajaran yang digunakan pada tabel 1.

Tabel 1. Tahap Pembelajaran PjBL Terintegrasi STEM

\begin{tabular}{cll}
\hline No & \multicolumn{1}{c}{ Tahap Pembelajaran PjBL } & Tahap STEM \\
\hline 1 & Pertanyaan Mendasar & Reflection \\
2 & Mendesain Perencanaan Proyek & Research \\
3 & Menyusun Jadwal Pembuatan Proyek & $\begin{array}{l}\text { Discovery } \\
\text { Application }\end{array}$ \\
4 & Memonitor Keaktifan dan & \\
& Perkembangan Proyek & Communication \\
5 & Menguji Hasil & Evaluation \\
6 & Evaluasi Pengalaman Belajar & modition \\
\hline
\end{tabular}

Lani et al. (2018) dari hasil penelitiannya diketahui bahwa model PjBL terintegrasi STEM 
lebih efektif dalam meningkatkan hasil belajar aspek pengetahuan, keterampilan, dan kreativitas siswa dibandingkan pembelajaran dengan model PjBL saja. Sebelumnya Jaka dan Ani (2016) juga telah melakukan penelitian penerapan PjBL terintegrasi STEM ternyata juga dapat meningkatkan pengetahuan, keterampilan, dan sikap ilmiah siswa.

\section{METODE PENELITIAN}

Penelitian ini menggunakan Penelitian Tindakan Kelas model Kemmis-Mc.Taggart. Model merupakan satu perangkat yang terdiri dari tiga komponen, yaitu: perencanaan, tindakan pengamatan (observasi), dan refleksi yang bertujuan untuk memperbaiki dan meningkatkan kualitas pembelajaran. Ketiga komponen yang berupa untaian tersebut dipandang sebagai satu siklus. Ketiga komponen tersebut dilaksanakan secara bertahap dan sistematis. Model ini digunakan untuk meningkatkan keterampilan kerja ilmiah siswa. Prosedur dari penelitian ini adalah: 1) Tahap persiapan, kegiatan pada tahap ini adalah menyesuaikan rencana pembelajaran, membuat soal pretest dan posttest, dan membuat lembar observasi. 2) Tahap pelaksanaan, adalah: a) memberikan pretest untuk mengetahui kemampuan belajar awal siswa, b) Melaksanakan pembelajaran dengan menggunakan model PjBL terintegrasi STEM dengan akuaponik, c) Selama pembelajaran berlangsung dilakukan pengamatan pada aktivitas siswa dalam pembelajaran PjBL terintegrasi STEM dengan akuaponik. d) Membuat rangkuman materi belajar, e) memberikan posttest. 3) Tahap Refleksi, yaitu memeriksa semua dokumen test dan lembar pengamatan serta mengidentifikasi masalah-masalah yang terjadi di siklus I yang menyebabkan kurang optimalnya hasil di siklus I berdasarkan hasil observasi dan test. Kemudian menyusun langkah siklus II berdasarkan masukan dari refleksi siklus I. Subjek dalam penelitian ini adalah 29 siswa kelas XII MIPA-3 SMA Negeri 1 Rawalo tahun pelajaran 2019/2020 pada materi pertumbuhan dan perkembangan makhluk hidup.

\section{HASIL PENELITIAN DAN PEMBAHASAN}

\section{Hasil Penelitian}

Hasil siklus I yang diperoleh dari proses pembelajaran dengan model PjBL terintegrasi STEM dengan akuaponik diharapkan dapat meningkatkan keterampilan kerja ilmiah siswa pada materi pertumbuhan dan perkembangan makhluk hidup. Siklus I terlaksana sebanyak empat kali pertemuan dengan langkah pembelajaran pada tabel 2 . 
Tabel 2. Aktivitas Pembelajaran

\begin{tabular}{|c|c|c|}
\hline No & Tahap & Kegiatan Siswa \\
\hline 1 & Reflection & Merefleksi materi sebelumnya \\
\hline 2 & Research & $\begin{array}{l}\text { Mengumpulkan informasi yang menunjang proyek } \\
\text { akuaponik }\end{array}$ \\
\hline 3 & Discovery & Membuat desain akuaponik dan mempresentasikannya. \\
\hline 4 & Application & $\begin{array}{l}\text { Membuat media akuaponik dan menggunakannya sebagai } \\
\text { proyek. }\end{array}$ \\
\hline 5 & Communication & $\begin{array}{l}\text { Mempresentasikan hasil proyek akuaponik dan menyusun } \\
\text { laporan. }\end{array}$ \\
\hline
\end{tabular}

Keterampilan kerja ilmiah siswa diukur pada saat proses pembelajaran berlangsung mulai dari tahap reflection, research, discovery, aplication, sampai tahap communication. Siswa memiliki keterampilan kerja ilmiah yang baik jika memperoleh nilai di atas 70 dan secara klasikal sebesar 70\%. Data pengukuran keterampilan bekerja ilmiah pada siklus I diperoleh hasil sebagai berikut:

Tabel 3. Persentase Ketuntasan Keterampilan Kerja Ilmiah

\begin{tabular}{rlrr}
\hline \multirow{2}{*}{ No. } & \multirow{2}{*}{ Aspek yang dinilai } & \multicolumn{2}{c}{ Hasil Ketuntasan } \\
\cline { 3 - 4 } & & Tuntas $(\%)$ & Tidak Tuntas (\%) \\
\hline 1 & Mengajukan pertanyaan & 77,27 & 22,73 \\
\hline 2 & Merencanakan percobaan & 63,64 & 36,36 \\
\hline 3 & Melakukan pengamatan & 95,45 & 4,55 \\
\hline 4 & Menggunakan alat/bahan & 100 & 0 \\
\hline 5 & Menganalisis hasil percobaan & 86,36 & 13,64 \\
\hline 6 & Menyusun laporan percobaan & 81,82 & 18,18 \\
\hline 7 & Membuat Kesimpulan & 100 & 0 \\
\hline 8 & Keterampilan presentasi & 90,91 & 9,09 \\
\hline
\end{tabular}

Untuk mengetahui pemahaman konsep siswa pada materi pertumbuhan dan perkembangan makhluk hidup dilakukan pre test sebelum pembelajaran dimulai dan setelah pembelajaran dilakukan post test. Pengukuran hasil belajar siswa yang memperoleh nilai di atas 75 sebagai berikut:

Tabel 4. Analisis Hasil Belajar Siswa

\begin{tabular}{clcc}
\hline No & Aspek Nilai & Pre-test & Post-test \\
\hline 1 & Nilai Rata-rata & 62,00 & 76,72 \\
2 & Persentase Tuntas & $17,24 \%$ & $68,97 \%$ \\
3 & Persentase Tidak Tuntas & $82,76 \%$ & $31,03 \%$ \\
\hline
\end{tabular}

Setelah dilakukan proses pembelajaran dengan menggunakan model PjBL terintegrasi STEM berbantuan akuaponik, pada siklus I diperoleh hasil bahwa telah terjadi peningkatan pada 
keterampilan kerja ilmiah siswa. Aspek keterampilan dalam menggunakan alat/bahan dan keterampilan dalam membuat kesimpulan sudah tuntas. Sedangkan aspek keterampilan mengajukan pertanyaan, merencanakan percobaan/penyelidikan, melakukan pengamatan, menganalisis hasil percobaan, menyusun laporan percobaan, dan keterampilan presentasi belum tuntas. Untuk meningkatkan aspek keterampilan kerja ilmiah siswa yang belum tuntas, maka pembelajaran dilanjutkan siklus II dengan tahap-tahap pembelajaran yang sama seperti siklus I dengan menjelaskan kembali keterampilan kerja ilmiah yang harus dikuasai siswa dalam mengerjakan proyek akuaponik. Selanjutnya siswa melakukan pembelajaran kembali dengan menggunakan alat, bahan, dan obyek akuaponik yang berbeda.

Siklus II dilakukan sebagaimana tindakan pada siklus I tetapi dengan menggunakan jenis tanaman dan jenis ikan yang berbeda. Siswa menentukan sendiri alat, bahan, dan obyek akuaponik yang akan digunakan. Selain itu juga adanya sentuhan perlakuan sesuai hasil refleksi pada siklus 1 yaitu memotivasi siswa lagi agar lebih aktif dan terampil dalam mengajukan pertanyaan, merencanakan percobaan/penyelidikan, melakukan pengamatan, menganalisis hasil percobaan, menyusun laporan percobaan, dan aktif dalam melakukan presentasi hasil proyek.

Setelah dilakukan perbaikan pada siklus II diperoleh hasil pengukuran keterampilan bekerja ilmiah dengan aspek mengajukan pertanyaan, merencanakan percobaan, melakukan pengamatan, melakukan pengamatan, menggunakan alat/bahan, menganalisis hasil percobaan, menyusun laporan percobaan, menyusun laporan percobaan, membuat kesimpulan, dan melakukan presentasi hasil sudah tuntas $100 \%$.

Pada tindakan siklus II tidak dilakukan pre test. Di akhir pembelajaran dilakukan post test dengan menggunakan standar kelulusan yang diperoleh hasil sebagai berikut:

Tabel 5. Analisis Hasil Belajar Siswa

\begin{tabular}{rlcc}
\hline No & Aspek Nilai & Pre-test & Post-test \\
\hline 1 & Nilai Rata-rata & - & $86,34 \%$ \\
2 & Persentase Tuntas & - & $100 \%$ \\
3 & Persentase Tidak Tuntas & - & $0 \%$ \\
\hline
\end{tabular}

\section{Pembahasan}

Penelitian ini dilaksanakan pada materi pertumbuhan dan perkembangan makhluk hidup dengan media akuaponik. Penelitian dilaksanakan dengan dua siklus. Siklus I dilaksanakan dengan empat pertemuan dan dilanjutkan perbaikan pada siklus II dengan dua pertemuan. Pembelajaran model PjBL terintegrasi STEM melalui tahap Reflection, yaitu siswa 
merefleksi materi yang pernah didapat sebelumnya dengan yang akan dipelajari; Research, yaitu siswa mengumpulkan informasi yang menunjang percobaan akuaponik yang akan dibuat; Discovery, yaitu siswa mencari penemuan-penemuan tentang akuaponik, menyusun desain akuaponik, mempresentasikan desain akuaponik. Jika layak maka desain aquaponik siap dijadikan produk, jika tidak layak siswa melakukan desain ulang sesuai dengan hasil presentasi; Aplication, yaitu siswa membuat produk akuaponik yang telah dirancang dilanjutkan dengan uji coba dan penanaman tanaman dan ikan. Siswa melakukan pengamatan pertumbuhan tanaman hidroponik selama dua minggu secara berkelompok; Communication, yaitu siswa mempresentasikan hasil pengamatan dan kemudian dilanjutkan dengan menyusun laporan percobaan.

Penelitian ini bertujuan untuk meningkatkan keterampilan bekerja ilmiah siswa melalui penerapan model PjBL terintegrasi STEM dengan media akuaponik. Sesuai langkah pembelajaran dengan model tersebut terbukti efektif untuk meningkatkan keterampilan bekerja ilmiah siswa. Hasil penelitian ini sesuai dengan hasil penelitian Lani et al. (2018) dan Capraro et al. (2013) yang melaporkan bahwa penerapan model PjBL terintegrasi STEM dalam pembelajaran dapat meningkatkan keterampilan siswa.

Seluruh siswa setelah dilakukan tindakan siklus I sudah memperoleh hasil sangat terampil dalam menggunakan alat/bahan percobaan. Penggunaan bahan-bahan bekas seperti botol plastik air mineral, ember plastik, busa jok motor, dan busa mebel yang sudah tidak terpakai untuk dimanfaatkan siswa menjadi media dalam pembuatan akuaponik. Hal tersebut dapat memotivasi siswa dalam mengerjakan kegiatan proyek. Pada pembelajaran model PjBL terintegrasi STEM pada tahap Discovery, siswa membuat desain ulang media akuaponiknya lagi jika ternyata belum sesuai atau gagal setelah dilakukan diuji coba dalam penggunaannya. Hal ini menjadikan siswa sangat terampil dalam menggunakan alat/bahan percobaan karena dilakukan secara berulang. Pada aspek keterampilan dalam merencanakan percobaan, pada siklus I hanya sebesar $63,64 \%$ siswa yang sudah terampil sedangkan yang masih kurang terampil sebesar 36,36\%. Hal ini disebabkan karena siswa belum terbiasa untuk melakukan sesuatu yang baru, sehingga masih merasa takut dan ragu-ragu untuk melakukannya. Setelah dilakukan tindakan pada siklus II, seluruh siswa sudah terampil dalam merencanakan percobaan.

Pembelajaran model PjBL terintegrasi STEM dengan media akuaponik juga dapat meningkatkan penguasaan konsep siswa pada materi pertumbuhan dan perkembangan makhluk hidup. Setelah mengikuti pembelajaran dengan model tersebut, penguasaan konsep siswa meningkat sebesar 9,62\%. Hasil ini sesuai dengan penelitian Saputra (2012), bahwa 
pengetahuan konsep siswa akan meningkat dengan optimal seiring dengan peningkatan keterampilan kerja ilmiah siswa. Hasil penelitian ini juga sesuai dengan hasil penelitian Jaka dan Ani (2016) yang menerapkan model PjBL terintegrasi STEM dapat meningkatkan pengetahuan siswa. Pembelajaran dengan model PjBL terintegrasi STEM dengan media akuaponik membutuhkan kerja sama, komunikasi antar siswa, keterampilan pemecahan masalah, serta manajemen diri. Selain itu juga siswa dituntut bekerja secara kolaboratif, terlibat dalam penyelesaian masalah, mendesain penyelidikan dan menilainya, serta membuat aktivitas inkuiri dan refleksi. Siswa dapat mengembangkan pengalaman belajar yang bermakna, sehingga dapat meningkatkan pengetahuan konsep siswa.

\section{SIMPULAN}

Model PjBL terintegrasi STEM dengan akuaponik dilaksanakan melalui tahap-tahap berikut: Reflection, merefleksi materi sebelumnya dengan yang akan dipelajari; Research, mengumpulkan informasi yang menunjang dalam percobaan akuaponik; Discovery, mencari referensi penemuan-penemuan tentang akuaponik, menyusun desain akuaponik, dan mempresentasikan desain akuaponik; Aplication membuat media akuaponik dan dilanjutkan dengan uji coba serta menggunakan sebagai proyek; Communication, mempresentasikan hasil pengamatan dan menyusun laporan percobaan. Model PjBL terintegrasi STEM dengan akuaponik dapat meningkatkan keterampilan kerja ilmiah siswa, yaitu keterampilan mengajukan pertanyaan, merencanakan percobaan, melakukan pengamatan, menggunakan alat/bahan, menganalisis hasil percobaan, membuat kesimpulan, menyusun laporan percobaan, dan keterampilan presentasi hasil percobaan. Model PjBL terintegrasi STEM dengan akuaponik dapat meningkatkan pengetahuan konsep siswa pada materi pertumbuhan dan perkembangan makhluk hidup sebesar 9,62\%.

\section{Saran}

Model PjBL terintegrasi STEM dengan akuaponik dapat digunakan untuk meningkatkan keterampilan bekerja ilmiah siswa. Untuk meningkatkan keterampilan siswa dalam merencanakan percobaan, guru perlu memberikan perhatian lebih pada tahap Discovery yaitu pada saat siswa membuat desain media akuaponik. 


\section{DAFTAR PUSTAKA}

Afriana, J. (2015). Project Based Learning (PjBL). Makalah untuk Tugas Mata Kuliah Pembelajaran IPA Terpadu. Program Studi Pendidikan IPA Sekolah Pascasarjana. Universitas Pendidikan Indonesia. Bandung.

Asmuniv. (2015). Listrik \& Elektro. Retrived from Vedc Malang.

Becker, K; \& Park, K. (2011). "Effects of integrative approaches among science, technology, engineering, and mathematics (STEM) subjects on students' learning: A preliminary meta-analysis." Journal of STEM Education, Volume 12.

Capraro, R. M; Capraro, M. M, Morgan, J. R; \& Slough, S. W. (2013). STEM Project-Based Learning: An Integrated Science, Technology, Engineering, and Mathematics (STEM) Approach. STEM Project-Based Learning an Integrated Science, Technology, Engineering, and Mathematics (STEM) Approach. Rotterdam: Sense Publisher.

Goodman; Brandon; \& Stivers, J. (2010). Project-Based Learning. Educational Psychology. ESPY, 505.

Grant, M.M. (2002). Getting A Grip of Project Based Learning : Theory, Cases and Recomandation. North Carolina : Meredian A Middle School Computer Technologies. Journal Vol. 5.

Jaka, A; Ani, F. (2016). Penerapan Project Based Learning Terintegrasi STEM Untuk Meningkatkan Literasi Sains Dan Kreativitas Siswa Ditinjau Dari Gender. Jurnal Inovasi Pendidikan IPA, 2(2): 202-212.

Laboy, R. (2010). Integrated STEM education through project-based learning. www.learning.com/stem/whitepaper/ integrated-STEM-through ProjectbasedLearning.

Lani, M.I.F; Sri, H; Shinta, M. (2018). Eksperimen Model Pembelajaran PjBL dan PjBLSTEM Untuk Meningkatkan Hasil Belajar dan Kreativitas Siswa Pada Kompetensi Teknologi Pengolahan Susu. Jurnal Penelitian Pendidikan : Vol. 35 Nomor I Tahun 2018.

Made, W. ( 2014). Strategi Pembelajaran Inovatif Kontemporer. Jakarta : PT Bumi Aksara.

Rustaman, N.Y. (2007). Pendidikan Biologi dan Tren Penelitiannya. Makalah Kunci dalam Seminar Nasional Biologi. FMIPA UPI Bandung.

Rustaman, N.Y. (2003). Kemampuan Dasar Bekerja Ilmiah dalam Sains. Makalah pada Seminar Pendidikan Biologi - FKIP UNPAS Bandung 
Ozer, D., Z.; \& Ozkan, M. (2012). The Effect of the Project Based Learning on the Science Process Skills of the Prospective Teachers of Science. Journal of Turkish Science Education. Vol 9 Issue 3, 131-136.

Saputra, H.J. (2012). Pembelajaran IPA Terpadu Melalui Keterampilan Kerja Ilmiah Untuk Mengembangkan Nilai Karakter. Prosiding Seminar Nasional Inovasi Pembelajaran FPMIPA IKIP PGRI Semarang. 12 Juli 2012.

Sanders, M; Hyuksoo, K; Kyungsuk, P; \& Hyonyong, L. (2011). Integrative STEM (Science, Technology, Engineering, and Mathematics) Education: Contemporary Trends and Issues. Secondary Education 59, 729-762. 